\title{
De rechterlijke lijdelijkheid in rook opgegaan? De ambtshalve toepassing van de consumentenkoopregels nader toegelicht
}

\author{
Mr.dr. A.G.F. Anceryen mr. dr. drs. C.M.D.S. Pavillon*
}

\section{Wat eraan voorafging}

Daar stond ze dan. Langs de A16, met haar dochtertje. Froukje Faber had vier maanden eerder, in mei 2008, voor $€ 7002$ een tweedehands Range Rover gekocht bij Autobedrijf Hazet Ochten $\mathrm{BV}^{1}$ (hierna: Hazet BV) en nu ging de auto opeens in vlammen op. Het autowrak werd weggesleept en zonder dat er een technisch rapport was opgemaakt, werd wat overbleef van de auto in mei 2009 op verzoek van Hazet BV gedemonteerd. In diezelfde maand stelde Faber Hazet BV aansprakelijk voor de door haar geleden schade. Die schade, bestaande uit de aankoopsom van de auto en de waarde van verscheidene voorwerpen die zich hierin bevonden, heeft zij op $€ 10.828,55$ begroot. De schade-expert kon haar verzoek om het voertuig te onderzoeken om begrijpelijke redenen - de auto was al gedemonteerd - niet honoreren.

Hazet BV wijst aansprakelijkheid van de hand. Volgens haar heeft Faber veel te laat geklaagd en hiermee haar rechten verspeeld. Wanneer Faber bij de Rechtbank Arnhem een rechtszaak aanspant op grond van (onder meer) de non-conformiteit van de gekochte auto (art. 7:17 van het Burgerlijk Wetboek, BW) beroept Hazet BV zich op art. 7:23 lid 1 BW. De rechtbank stelt Hazet BV in april 2011 in het gelijk. Faber heeft overigens niet gesteld dat zij de auto als consument had gekocht, maar naar het oordeel van de rechtbank kan de hoedanigheid waarin Faber de auto heeft gekocht in het midden blijven.

Faber komt in juli 2011 in hoger beroep van het afwijzend vonnis bij het Hof Arnhem-Leeuwarden. $\mathrm{Zij}$ beweert op de dag van de brand al bij Hazet BV te hebben geklaagd over de gekochte auto en haar klachten tijdens een telefoongesprek

* Mr. dr. A.G.F. Ancery is gerechtsauditeur bij de Hoge Raad der Nederlanden, universitair docent privaatrecht aan de Rijksuniversiteit Groningen en redacteur van dit tijdschrift. Mr. dr. drs. C.M.D.S. Pavillon is universitair docent privaatrecht aan de Universiteit Leiden. Mr. dr. A.G.F. Ancery schrijft deze bijdrage op persoonlijke titel.

1. Overigens lijkt het HvJ blijkens r.o. 33 aan te nemen dat ook de verkoper een particulier is. Het is ons niet duidelijk waarop het $\mathrm{HvJ}$ dit baseert. ruim een halfjaar later te hebben herhaald. Hazet BV betwist deze stellingen daar Faber hiervoor geen bewijs heeft geleverd dan wel aangeboden. Wederom laat Faber na te stellen dat zij de auto als consument heeft gekocht. Het hof ziet zich genoodzaakt om de volgende zeven prejudiciële vragen te stellen:

'1. Is de nationale rechter, hetzij op grond van het effectiviteitsbeginsel, hetzij op grond van het met Richtlijn 1999/44 beoogde hoge niveau van consumentenbescherming binnen de Unie, hetzij op grond van andere bepalingen of normen van Unierecht verplicht ambtshalve te onderzoeken of de koper bij een overeenkomst (een) consument in de zin van artikel I lid 2 sub a van Richtlijn $1999 / 44$ is?

2. Indien het antwoord op de eerste vraag bevestigend luidt, geldt dit ook indien het procesdossier geen (of onvoldoende of tegenstrijdige) feitelijke informatie bevat om de hoedanigheid van de koper te kunnen vaststellen?

3. Indien het antwoord op de eerste vraag bevestigend luidt, geldt dit ook voor een procedure in hoger beroep, waarin de koper geen grieven heeft gericht tegen het vonnis van de rechter in eerste aanleg, voor zover in dat vonnis dat (ambtshalve) onderzoek niet is verricht, en daarin de vraag of de koper als een consument kan worden aangemerkt uitdrukkelijk in het midden is gelaten?

4. Moet (artikel 5 van) Richtlijn 1999/44 worden beschouwd als een norm die gelijkwaardig is aan de nationale regels die in de interne rechtsorde als regels van openbare orde gelden?

5. Verzetten het effectiviteitsbeginsel, dan wel het met Richtlijn 1999/44 beoogde hoge niveau van consumentenbescherming binnen de Unie, dan wel andere bepalingen of normen van Unierecht zich tegen het Nederlandse recht ten aanzien van stelplicht en bewijslast van de consument-koper met betrekking tot de plicht tot (tijdige) kennisgeving van het veronderstelde gebrek van een afgeleverd goed aan de verkoper? 


\section{Maandblad}

6. Verzetten het effectiviteitsbeginsel, dan wel het met Richtlijn 1999/44 beoogde hoge niveau van consumentenbescherming binnen de Unie, dan wel andere bepalingen of normen van Unierecht zich tegen het Nederlandse recht ten aanzien van stelplicht en bewijslast van de consument-koper dat het goed non-conform is en dat deze nonconformiteit zich binnen zes maanden na aflevering heeft geopenbaard? Wat betekenen de woorden "Manifesteert zich een gebrek aan overeenstemming" in artikel 5 lid 3 van de Richtlijn 1999/44 en met name: in welke mate moet de consument-koper feiten en omstandigheden stellen die (de oorzaak van) de non-conformiteit betreffen? Is daarvoor voldoende dat de consument-koper stelt en bij gemotiveerde betwisting bewijst dat het gekochte niet (goed) functioneert of dient hij ook te stellen en bij gemotiveerde betwisting te bewijzen welk gebrek aan het verkochte dit niet (goed) functioneren veroorzaakt (heeft)?

7. Speelt bij de beantwoording van de voorafgaande vragen nog een rol dat Faber zich in deze procedure in beide instanties heeft laten bijstaan door een advocaat?'

Het Hof van Justitie van de Europese Unie (hierna: HvJ) heeft het antwoord op de eerste drie alsmede zevende vraag gebundeld. Vraag 4, 5 en 6 zijn van een afzonderlijk antwoord voorzien. In deze bijdrage hebben we gekozen voor een tweeluik. Eerst zullen we in paragraaf 2 ingaan op de antwoorden van het $\mathrm{HvJ}$ op vragen inzake de ambtshalve vaststelling van de toepasselijkheid van de Richtlijn consumentenkoop (fase één, vraag $1 \mathrm{t} / \mathrm{m} \mathrm{3}$ ). Deze antwoorden zijn weinig verrassend, maar roepen een aantal voor de praktijk relevante vragen op, zoals de vraag welke feiten de rechter wanneer moet verzamelen en de vraag wie onder welke voorwaarden als consument moet worden aangemerkt. In paragraaf 3 bespreken we de antwoorden op de vragen betreffende de toepassing van de koopregeling (fase twee, vragen $4 \mathrm{t} / \mathrm{m} \mathrm{6}$ ). De klachtplicht van art. 7:23 lid $1 \mathrm{BW}$ (vraag 5) en het bewijsvermoeden van art. 7:18 lid 2 BW (vraag 6) worden voor het eerst door het HvJ toegelicht. Wij zullen nagaan in hoeverre de antwoorden van het $\mathrm{HvJ}$ een einde maken aan de bestaande onduidelijkheden met betrekking tot de bewijslastverdeling bij beide leerstukken en in hoeverre de rechter in de toepassingsfase verplicht is om ambtshalve op te treden.

\section{De toepasselijkheid van de Richtlijn consumentenkoop: fase één}

Het hoofdstuk van de Richtlijn consumentenkoop ${ }^{2}$ is voor wat betreft de ambtshalve toepassing anderhalf jaar geleden geopend met het Duarte Hueros-arrest. ${ }^{3}$ In het Faber-arrest wordt verder aan dit hoofdstuk geschreven. Waar het eerste arrest om een nieuwe auto ging, draait het in het tweede arrest

2. Richtlijn $1999 / 44$ betreffende bepaalde aspecten van de verkoop van en de garanties voor consumentengoederen, PbEG 1999, L 171/12, laatstelijk gewijzigd bij de Richtlijn consumentenrechten (2011/83/EU, PbEG, L 304/64 e.v.).

3. HvJ EU 3 oktober 2013, C-32/12, ECLI:EU:C:2013:637, TvC 2014/3 m.nt. A.G.F. Ancery (Soledad Duarte Hueros/Autociba SA en Automóviles Citroën España SA). om een gebruikte auto. Deze Europese jurisprudentie is representatief voor de nationale jurisprudentie waarin de koopregeling vaak wordt ingeroepen bij kapotte (vooral gebruikte ${ }^{4}$ ) auto's. ${ }^{5}$

\subsection{De lekkende cabrio}

In het Duarte Hueros-arrest werd al duidelijk dat de nationale rechter ook in het kader van de Richtlijn consumentenkoop niet ontkomt aan een actievere rol. De Richtlijn consumentenkoop beoogt immers een hoog niveau van consumentenbescherming en de rechtspraak van het $\mathrm{HvJ}$ in zaken over oneerlijke bedingen en consumentenkrediet leerde al dat zo'n hoog niveau van consumentenbescherming niet kan worden bereikt zonder dat de rechter ambtshalve toepassing geeft aan consumentenbeschermende bepalingen. ${ }^{6}$ De consument is vaak onwetend van zijn rechten of ondervindt moeilijkheden bij het uitoefenen van die rechten. Als de rechter dan niet ambtshalve toepassing geeft aan die bepalingen, blijft de consument wellicht verstoken van datgene waar hij recht op heeft.

De zaken die vallen onder de reikwijdte van de Richtlijn consumentenkoop zijn echter niet te vergelijken met de zaken die vallen onder de reikwijdte van de Richtlijn oneerlijke bedingen. Waar voor de laatste categorie zaken kenmerkend is dat de consument niet in rechte verschijnt en de toepassing van een potentieel oneerlijk beding dus buiten hem om zou geschieden, is toepassing van de remedies die de consument worden toegekend onder de Richtlijn consumentenkoop niet goed denkbaar zonder dat de consument in het geding verschijnt. Het probleem dat daar optreedt, is dat de consument vaak de verkeerde remedie kiest. En wat dient de rechter dan te doen? De Richtlijn consumentenkoop vermeldt in art. 3 jo. art. 11 lid 1 dat lidstaten de nodige maatregelen treffen om te verzekeren dat de consument zijn rechten daadwerkelijk kan uitoefenen. Brengt dat ook een plicht tot ambtshalve toepas-

4. De zogenaamde 'market for lemons'. Lemon ('citroen') is Amerikaans slang voor een auto die defect blijkt te zijn na aankoop.

5. Zie bijv. Hof Den Haag 11 oktober 2011, ECLI:NL:GHSGR: 2011:BT7574.

6. HvJ EG 27 juni 2000, C-240-244/98, Jur. 2000, p. I-4941, NJ 2000/730 (Océano); HvJ EG 21 november 2002, C-473/00, Jur. 2002, p. I-10875, NJ 2003/703 m.nt. M.R. Mok (Cofidis); HvJ EG 26 oktober 2006, C-168/05, Jur. 2006, p. I-10421, NJ 2007/201 m.nt. M.R. Mok (Mostaza Claro); HvJ EG 4 oktober 2007, C-429/05, Jur. 2007, p. I-08017, NJ 2008/37 m.nt. M.R. Mok (Rampion); HvJ EG 4 juni 2009, C-243/08, Jur. 2009, p. I-4713, NJ 2009/395 m.nt. M.R. Mok (Pannon); HvJ EG 6 oktober 2009, C-40/08, Jur. 2009, p. I-9579, NJ 2010/11 m.nt. M.R. Mok (Asturcom); HvJ EG 17 december 2009, C-227/08, Jur. 2009, p. I-11939, NJ 2010/225 m.nt. M.R. Mok (Martín Martín); HvJ EU 9 november 2010, C-137/08, Jur. 2010, p. I-10847, NJ 2011/41 m.nt. M.R. Mok (Pénzügyi); HvJ EU 16 november 2010, C-76/10, Jur. 2010, p. I-11557 (Pohotovost); HvJ EU 26 april 2012, C-472/10, NJ 2012/404 m.nt. M.R. Mok (Invitel); HvJ EU 15 maart 2012, C-453/10, NJ 2012/330 m.nt. M.R. Mok (Perenicova); HvJ EU 14 juni 2012, C-618/10, NJ 2012/512 m.nt. M.R. Mok (Banesto); HvJ EU 21 februari 2013, C-472/11, NJ 2013/326 m.nt. M.R. Mok (Banif); HvJ EU 30 mei 2013, C-397/11, NJ 2013/486 m.nt. M.R. Mok (Jörös); HvJ EU 30 mei 2013, C-488/11, NJ 2013/487 m.nt. M.R. Mok (Asbeek Brusse); HvJ EU 3 oktober 2013, C-32/12 (Duarte Hueros); HvJ EU 17 juli 2014, C-169/14, NJ 2015/53 m.nt. M.R. Mok (Banco Bilbao); HvJ EU 12 februari 2015, C-567/13, RCR 2015/36 (Baczó en Visznyiczai). 
sing van die remedies met zich? In het Duarte Hueros-arrest geeft het $\mathrm{HvJ}$ slechts aan dat het 'aan de verwijzende rechter [is] (...) om binnen zijn bevoegdheden, met inachtneming van het gehele interne recht en onder toepassing van de daarin erkende uitleggingsmethoden, al het mogelijke te doen om de volle werking van artikel 3, lid 5, van richtlijn 1999/44 [de remedies in geval van non-conformiteit; AGFA \& CMDSP] te verzekeren' en dat de Richtlijn consumentenkoop zich verzet tegen 'een regeling, (...) waarbij de nationale rechter bij wie het geding aanhangig is, wanneer een consument die recht heeft op een redelijke vermindering van de in de koopovereenkomst vastgestelde prijs van een zaak enkel ontbinding van de overeenkomst vordert, maar de overeenkomst niet kan worden ontbonden omdat de non-conformiteit van de zaak gering is, niet ambtshalve een dergelijke vermindering kan toewijzen, hoewel de consument zijn oorspronkelijke vordering niet nader mag specificeren en evenmin een nieuwe procedure aanhangig mag maken [curs. AGFA \& CMDSP]'. Zou dit wel mogelijk zijn, dan is een ambtshalve optreden niet geboden. In het Duarte Hueros-arrest heeft het HvJ niet expliciet geoordeeld dat onder de nodige maatregelen van art. 3 jo. art. 11 lid 1 van de Richtlijn consumentenkoop ook dient te worden begrepen dat de rechter ambtshalve toepassing geeft aan een van de remedies, desnoods buiten de grenzen van de rechtsstrijd. ${ }^{7}$

De in het Duarte Hueros-arrest gestelde vraag speelt zich af in 'fase twee' van de ambtshalve toepassing van consumentenrecht. Om in fase twee te belanden - kort gezegd, de fase waarin de rechter de consument ambtshalve verzekert van de hem toekomende materiële bescherming - moet zijn vastgesteld dat de kwestie valt binnen de reikwijdte van een consumentenbeschermende EU-richtlijn. Voor wat betreft de Richtlijn oneerlijke bedingen heeft de rechter in die voorfase - fase één - een onderzoeksplicht om vast te stellen of de kwestie valt binnen de reikwijdte van die richtlijn. Geldt een dergelijke plicht ook bij de Richtlijn consumentenkoop? En wat wordt er van de rechter in fase twee precies verwacht? De eerste vraag is voorgelegd door het Hof Arnhem-Leeuwarden, de tweede vraag helaas niet. De vraag naar de mate van activiteit van de rechter in fase twee is in deze procedure beperkt tot de vraag of het bewijsvermoeden van art. 7:18 lid 2 BW ambtshalve moet worden toegepast (zie par. 3.3).

\subsection{De brandende auto en de kwalificatie van de rechtsverhouding}

In het Faber-arrest ligt de vraag naar de rol van de rechter in zaken betreffende een consumentenkoop dus weer in volle glorie voor. En nu biedt het HvJ iets meer duidelijkheid. Het vertrekpunt van het $\mathrm{HvJ}$ is immers nog enigszins wonderlijk te noemen. Waar het HvJ zich in de consumentenzaken die zien op oneerlijke bedingen of consumentenkrediet niets gelegen laat liggen aan de (on)mogelijkheden van het nationale proces-

7. Anders: A.S. Hartkamp, Ambtshalve toepassing van Europees consumentenrecht. Een nieuw hoofdstuk: de richtlijn consumentenkoop, AAe maart 2015, p. 225-226, die in het arrest zelfs het ultra petitum-verbod opzijgeschoven ziet. recht, de rechter onmiddellijk belast met een plicht tot ambtshalve toetsing en zelfs een onderzoeksplicht op hem legt om vast te stellen of de zaak überhaupt onder de reikwijdte van de betreffende consumentenbeschermende EU-richtlijn valt, ${ }^{8}$ begint het $\mathrm{HvJ}$ in het Faber-arrest met het vermelden van het beginsel van procedurele autonomie.

Waar het EU-recht niet voorziet in een regeling met betrekking tot de vraag of er ambtshalve onderzocht dient te worden of de koper als consument kan worden aangemerkt, dienen de nationale procesregels te worden toegepast, zij het dat deze regels niet ongunstiger mogen zijn dan de procesregels die in vergelijkbare nationaalrechtelijke geschillen gelden (gelijkwaardigheidsbeginsel) en de uitoefening van de door het EUrecht aan de consument toegekende rechten niet praktisch onmogelijk of uiterst moeilijk maken (effectiviteitsbeginsel). ${ }^{9}$ Deze twee beginselen worden samen wel aangeduid als de Rewe-beginselen, in lijn met een van de twee arresten waarin zij voor het eerst werden geformuleerd. ${ }^{10}$ Wellicht was dit ook wel het vertrekpunt in de in noot 6 vermelde consumentenrechtelijke arresten met betrekking tot de Richtlijn oneerlijke bedingen en de Richtlijn consumentenkrediet, maar het HvJ verwijst in die arresten noch naar het beginsel van procedurele autonomie, noch naar de gelijkwaardigheids- en effectiviteitstoets. Wellicht is de route die het HvJ in het Faber-arrest volgt wel logischer. Het EU-recht voorziet immers in de regel niet in procesrechtelijke regels en is voor de verwezenlijking van zijn regels afhankelijk van de nationale rechtsstelsels.

Als het nationale procesrecht steeds onverkort zou kunnen worden toegepast, zouden nationale procesregels de uitoefening van het EU-recht echter onmogelijk kunnen maken. Een extreem voorbeeld zou in dat kader kunnen zijn, een nationale procesregel die een kortere verjaringstermijn voor EU-vorderingen dan voor nationale vorderingen bepaalt. Om dat te voorkomen dienen nationale procesregels dan ook te worden getoetst aan het gelijkwaardigheids- en effectiviteitsbeginsel. Maar ook als het nationale procesrecht de toets aan het gelijkwaardigheids- en effectiviteitsbeginsel kan doorstaan, kan het nog steeds zo zijn dat een consument wel beschikt over een uit een EU-richtlijn voortvloeiend materieel recht, bijvoorbeeld een recht op een ontbinding bij non-conformiteit, maar dit recht niet kan verwezenlijken omdat hij niet over een voldoende effectief rechtsmiddel beschikt. Zo'n situatie kan bijvoorbeeld bestaan als de consument een excessief hoog bedrag zou moeten betalen om toegang te krijgen tot de rechter. Blijkens de arresten van het HvJ over de Richtlijn oneerlijke bedingen bestaat zo'n situatie ook als de consument, onwetend van zijn rechten, niet tegemoet wordt gekomen door de rechter die die rechten ambtshalve voor hem toepast. Anders zou de consument wel een recht hebben, maar geen reële mogelijkheid om

8. Vgl. noot 6. Zie ook A.G.F. Ancery, Ambtshalve toepassing van EU-recht (diss. Groningen), Deventer: Kluwer 2012, p. 110 e.v.

9. HvJ EU 4 juni 2015, C-497/13 (Faber/Hazet Ochten), r.o. 37.

10. HvJ EU 16 december 1976, C-45/76, Jur. 1976, p. 2043 (Comet) en HvJ EU 16 december 1976, C-33/76, Jur. 1976, p. 1989 (Rewe). 
dat recht ook te verwezenlijken. Kortom, de Rewe-toets is een andere toets dan die van de effectieve rechtsbescherming.

Het HvJ begint in het Faber-arrest als gezegd met de Rewetoets. Als dit vertrekpunt wordt vergeleken met de andere arresten over de ambtshalve toetsing aan consumentenbeschermende bepalingen valt wel op dat het $\mathrm{HvJ}$ daar onmiddellijk aanvaardt dat de consument zonder ambtshalve ingrijpen door de rechter een voldoende effectieve rechtsbescherming zou ontberen. ${ }^{11}$ Wat bedoelt het HvJ dan in de Faber-zaak? Ook in zaken over de consumentenkoop speelt toch de ratio die het $\mathrm{HvJ}$ in eerdere zaken tot een vergaande plicht tot activiteit deed leiden? Ook bij de consumentenkoop is de consument immers onwetend van zijn rechten of ondervindt hij moeilijkheden bij de uitoefening ervan. Is het $\mathrm{HvJ}$ van oordeel dat de Nederlandse consument-koper al beschikt over een voldoende effectief rechtsmiddel? Dat laatste zou heel goed het geval kunnen zijn. Het HvJ releveert in r.o. 38 e.v. dat de Nederlandse rechter ambtshalve de rechtsverhouding tussen partijen moet kwalificeren ${ }^{12}$ en in voorkomende gevallen om verduidelijking kan vragen op voet van art. 22 van het Wetboek van Burgerlijke Rechtsvordering (Rv). Wellicht ziet het $\mathrm{HvJ}$ hierin al een voldoende effectieve rechtsbescherming. Hiermee is dan wel weer moeilijk te rijmen dat in r.o. 44 e.v. de regel dat de consument zelf een beroep zou moeten doen op zijn consument-zijn, niet volstaat.

In het Faber-arrest lijkt het HvJ te suggereren dat het doet aan stating the obvious. Wat de rechter moet doen, kan al naar Nederlands recht. Dat is weliswaar juist, maar daarvoor heeft de rechter wel feiten nodig. Voor die feiten is hij afhankelijk van partijen en juist in de Faber-zaak kwamen partijen niet met de feiten over de brug aan de hand waarvan de rechter had kunnen geraken tot het oordeel dat het om een b2c-verhouding ging. En dan is het wel relevant om te weten of de rechter in zo'n geval ambtshalve moet zoeken naar die feitelijke informatie om de consument effectief te beschermen, gelijk de Pénzügyi-zaak, of dat de rechter dat moet doen omdat het nationale recht hem die mogelijkheid biedt, dit op grond van het gelijkwaardigheidsbeginsel (dus de Rewe-route). In het laatste geval voltrekt de verplichte toepassing zich immers via het nationale recht en hoeft de rechter niet geforceerd feitelijk onderzoek te gaan verrichten. De Nederlandse rechter beschikt immers over de mogelijkheid van art. $22 \mathrm{Rv}$, op basis waarvan de rechter partijen kan bevelen bepaalde stellingen toe te lichten of bescheiden te overleggen en bij weigering de

11. Het onderscheid tussen een rechtsmiddel en procesrechtelijke regels is treffend beschreven door Van Gerven: W. van Gerven, Of Rights, Remedies and Procedures, CMLR 2000, p. 501-536. In zijn indeling zouden de consumentrechtelijke arresten van het $\mathrm{HvJ}$ in de categorie rechtsmiddelen kunnen worden geplaatst. Zonder ambtshalve ingrijpen van de rechter ontbeert de consument een voldoende effectief rechtsmiddel.

12. Vgl. HR 15 mei 1998, NJ 1998/625 (Van Rooij/Van der Sluijs), r.o. 3.2; H.J. Snijders, C.J.M. Klaassen \& G.J. Meijer, Nederlands burgerlijk procesrecht, Deventer: Kluwer 2011, nr. 45a (p. 53-54). gevolgtrekking kan maken die hij geraden acht. ${ }^{13}$ Het laat zich denken dat die gevolgtrekking zou kunnen zijn dat de rechter aanvaardt dat het gaat om een b2c-verhouding.

Bij nadere lezing stuiten wij echter op een inconsistentie: het wordt eigenlijk helemaal niet aan het nationale procesrecht overgelaten of de rechter de rechtsverhouding ambtshalve kan kwalificeren. Het HvJ haalt in r.o. 42 wederom de ratio voor de plicht tot ambtshalve toetsing uit de andere arresten aan en stelt dat de bescherming die de Richtlijn consumentenkoop aan de consument wil bieden uiterst moeilijk zou kunnen worden gemaakt als de consument zelf zijn rechtsverhouding juridisch zou moeten kwalificeren om voor toepassing van de consumentenbeschermende bepalingen in aanmerking te komen (zie ook r.o. 44). Kortom, het effectiviteitsbeginsel staat eraan in de weg dat de rechter niet ambtshalve zou vaststellen dat de zaak onder de reikwijdte van de Richtlijn consumentenkoop valt, mits hij beschikt over de daarvoor benodigde gegevens, feitelijk en rechtens. Deze plicht geldt overigens pas als de uit de Richtlijn consumentenkoop voortvloeiende rechten in het geding zijn. Anders gezegd, de rechter moet eerst over de schutting van de kwalificatiefase kijken of een van de uit de Richtlijn consumentenkoop voortvloeiende materiële (consumentenbeschermende) rechten in het geding is alvorens te beoordelen of aan dat aspect kan worden toegekomen. In onderhavig geval zou hebben meegespeeld dat het wettelijke garantierecht waar de consument zich op beroept, bestaat in een tweetal smaken: de variant die van toepassing is op b2cverhoudingen en de variant die van toepassing is op de andere verhoudingen. In een dergelijk geval moet de verhouding tussen partijen sowieso eerst worden gekwalificeerd.

Daar blijft het overigens niet bij. De onderzoeksplicht van het Pénzügyi-arrest (dat ziet op de oneerlijke bedingen) wordt doorgetrokken naar de consumentenkoop. Maar die onderzoeksplicht lijkt minder ver te gaan, of wellicht vormt dit een verduidelijking van de onderzoeksplicht en geldt de inperking ook bij zaken die de Richtlijn oneerlijke bedingen betreffen. Hoe het ook zij, de rechter moet onderzoek doen als hij weliswaar niet beschikt over de voor de kwalificatie noodzakelijke gegevens, maar die gegevens wel na eenvoudig verzoek om verduidelijking kan verkrijgen, zo lezen we in r.o. 46. In het Nederlandse civiele proces zou de rechter dat kunnen doen door aanwending van zijn in art. 21 en $22 \mathrm{Rv}$ neergelegde bevoegdheden tot het bevelen tot toelichting van stellingen en/of het overleggen van bescheiden. De rechter zou bij gebrek aan aanwijzingen van het tegendeel over de vraag of de zaak onder de reikwijdte van de Richtlijn consumentenkoop valt, er dan voorshands van uit kunnen gaan dat dit het geval is en het aan de professionele partij kunnen laten om met bescheiden te komen die het tegendeel aannemelijk maken. Recent werd een

13. C.J-A. Seinen, De gevolgtrekking die hij geraden acht, TCR 2014, afl. 3, p. 84-95. 


\section{Maandblad}

voorstel gedaan voor een standaardformulier dat daarbij gebruikt zou kunnen worden. ${ }^{14}$

Het HvJ merkt bij dit al nog op dat deze plicht ook geldt als de consument wordt bijgestaan door een advocaat, aangezien deze verplichting losstaat van de concrete omstandigheden van het geval. Eigenlijk was dit punt al verduidelijkt in het Rampion-arrest. ${ }^{15}$

Fase één van de plicht tot ambtshalve toetsing bij zaken betreffende de consumentenkoop verschilt dus niet (wezenlijk) van fase één bij de plicht tot ambtshalve toetsing bij zaken betreffende oneerlijke bedingen. Het begint dus allemaal bij de vaststelling of de rechtsverhouding kan worden gekwalificeerd als een b2c-verhouding, en in lijn daarmee of een van de partijen kan worden aangemerkt als consument.

\subsection{Wie is consument? Fase één in concreto}

De vraag wie als consument heeft te gelden, is niet gesteld door de verwijzende rechter en het HvJ staat dan ook niet stil bij de definitie van een consument. De ambtshalve vaststelling van de toepasselijkheid van de richtlijn betreft een toetsing aan de Europeesrechtelijke definitie van de consument-koper. Het is lidstaten toegestaan om het toepassingsgebied van de Richtlijn consumentenkoop uit te breiden naar niet-consumenten, ${ }^{16}$ maar daar heeft de Nederlandse wetgever niet voor gekozen. Volgens art. 7:5 lid $1 \mathrm{BW}$ is in lijn met de richtlijndefinitie sprake van een consumentenkoop als de koop met betrekking tot een roerende zaak wordt gesloten door de verkoper die handelt in de uitoefening van een beroep of bedrijf en een koper, een natuurlijke persoon die niet handelt in de uitoefening van een beroep of bedrijf. Of een koper handelt in de uitoefening van een beroep of bedrijf wordt bepaald door het door de koper nagestreefde doel. Dit doel mag niet beroepsmatig zijn en het maakt hierbij niet uit of een handelaar buiten zijn normale bedrijfsactiviteiten handelt, zo maakt het $\mathrm{HvJ}$ duidelijk in het Di Pinto-arrest. ${ }^{17}$ Een bedrijfsmatige koop wordt nooit een consumentenkoop. Ingewikkelder ligt het bij gemengde overeenkomsten. Stel dat een auto enkel voor privégebruik (kinderen van school ophalen, vakantie en boodschappen) wordt gekocht, dan is er geen vuiltje aan de lucht. Het gaat om een consumentenkoop. Minder duidelijk is het wanneer de koper een zzp'er is, die de auto ook vaak zal gebruiken voor bezoeken aan klanten of leveranciers. Ons komt voor dat het aanschaffen van een auto soms een gemengde overeenkomst vormt.

14. A.G.F. Ancery \& C.J-A. Seinen, Vorderingen in b2c-verstekken: toetsen of toewijzen, TCR 2015, afl. 3, p. 87-88.

15. HvJ EG 4 oktober 2007, C-429/05, Jur. 2007, p. I-8017 (Rampion), r.o. 65.

16. Annotatie bij Hof Arnhem-Leeuwarden 13 mei 2014 , ECLI:NL:GHARL:2014:3884, TvC 2014, afl. 6, p. 291-295 (Telefoongids.com BV/Stichting Gilde Utrecht); M.B.M. Loos, Algemene voorwaarden, Den Haag: Boom Juridische uitgevers 2013, nr. 27.

17. HvJ EG 14 maart 1991, C-361/89, Jur. 1991, p. I-1189 (Di Pinto), Parl. Gesch. Boek 6 (Inv. 3, 5 en 6), p. 1662
De vraag is hoe onbeduidend het beroepsmatige doel moet zijn om bij een gemengde overeenkomst toch nog van een consumentenovereenkomst te kunnen spreken. In het Gruberarrest, ${ }^{18}$ waarin art. 13 van het Executieverdrag centraal staat, bepaalde het $\mathrm{HvJ}$ dat een koper met beroepsmatige doeleinden zich niet op genoemde bepaling ter bescherming van de consument mag beroepen, 'tenzij het beroepsmatige gebruik dermate marginaal is dat het in de globale context van de betrokken verrichting onbetekenend is'. Dat het niet-beroepsmatige aspect zwaarder weegt, achtte het HvJ niet relevant. In zijn conclusie voor het recente Costea-arrest, ${ }^{19}$ waarin sprake is van een kredietnemer die een aan hem toebehorend bedrijfspand als onderpand voor de afgesloten lening heeft gegeven, voorziet A-G Cruz de 'consument' uit de Richtlijn oneerlijke bedingen van een ruimere definitie: beslissend is dat het beroepsmatige doel niet overheerst binnen de globale context van de overeenkomst'. Het HvJ beschouwt de leningsovereenkomst echter niet als een gemengde overeenkomst ${ }^{20}$ en laat in zijn arrest de verhouding tussen beroepsmatig en privédoel helaas in het midden (r.o. 30).

De definitie uit de Richtlijn consumentenkoop is (nog) niet autonoom door het HvJ uitgelegd, maar gelet op de consumentenrechtelijke aard van de richtlijn ligt het niet voor de hand om aansluiting te zoeken bij het Gruber-arrest. De rechter kan wat ons betreft - net als A-G Cruz - aanhaken bij de soepelere definitie uit nr. 17 van de considerans bij de Richtlijn consumentenrechten. ${ }^{21}$ De Nederlandse wet staat een ruime benadering ook zonder meer toe. Hoewel de Nederlandse wetgever het toepassingsgebied van de regels ter omzetting van de Richtlijn consumentenkoop heeft beperkt tot de consumentenkoop, blijkt niet uit de parlementaire geschiedenis dat hij bij de omzetting van een strikte opvatting is uitgegaan. ${ }^{22}$ In het licht van bovenstaande zou in casu dus bepalend zijn of het privégebruik van de auto overheerst.

De rechter moet volgens het HvJ zelf de hoedanigheid van de koper vaststellen als deze zich niet uitdrukkelijk op zijn 'consument-zijn' beroept. Om over te gaan tot een nader onderzoek naar de hoedanigheid van de koper moet de rechter een aanwijzing hebben dat er mogelijk sprake is van een consument, zoals in casu de titel van de overeenkomst: 'Koopovereenkomst particulier' (r.o. 40). De vraag is of, als sprake is van

18. HvJ EG 20 januari 2005, C-464/01, Jur. 2005, p. I-439 (Gruber/Bay Wa $A G)$.

19. HvJ EU 3 september 2015, C-110-4, nog niet gepubliceerd (Costea).

20. Dat het bedrijfspand als onderpand voor de lening gold, doet er volgens het $\mathrm{HvJ}$ niet toe.

21. In zijn conclusie voor het Costea-arrest verwijst A-G Cruz naar de totstandkoming van de Richtlijn consumentenrechten en naar de considerans bij deze richtlijn (overweging nr. 17). Hieruit blijkt dat bij consumentenrichtlijnen afstand moet worden genomen van de restrictieve toepassing van het begrip consument uit het Gruber-arrest. Zie Loos 2013, nr. 27.

22. Art. 7:5 lid $1 \mathrm{BW}$ definieert de consument als 'natuurlijk persoon, die niet handelt in de uitoefening van beroep of bedrijf. Dat de Richtlijn consumentenkoop een minimumrichtlijn betreft, doet er overigens niet toe: het gaat hier om de (extra) bescherming van de niet-consument. 
een dergelijke aanwijzing, bij de rechter nog twijfel kan bestaan over de hoedanigheid van de consument en dus behoefte aan nader onderzoek. Het arrest rept niet over een vermoeden, maar naar Nederlands recht mag de rechter op grond van de hem beschikbare gegevens voorshands maar weerlegbaar het vermoeden baseren dat sprake is van een consument zonder hier verder onderzoek naar te doen. Volgens ons is, in lijn met het LOVCK-rapport, de afwezigheid van aanwijzingen dat sprake is van een professionele koper reeds voldoende voor het vermoeden dat sprake is van een consument. ${ }^{23}$ Deze aanpak heeft als voordeel dat de verkoper aan zet is en dat ook de niet-verschenen (vermoedelijke) consument wordt beschermd. Het is dan de verkoper die dient te stellen en te bewijzen dat er sprake is van een b2b-verhouding. In zaken met betrekking tot de koopregeling doen verstekzaken zich niet vaak voor, daar het meestal de consument is die een beroep doet op de door deze regeling geboden remedies. ${ }^{24} \mathrm{Als}$ de consument zelf verschijnt, kan de rechter indien nodig bij hem informeren naar zijn hoedanigheid. Dit navragen hoort bij het onderzoek dat de rechter moet instellen als hij twijfelt. Die twijfel, dat wil zeggen de noodzaak van nader onderzoek, zal niet zozeer ontstaan omdat er helemaal geen aanwijzingen zijn betreffende de hoedanigheid van de koper (dat zal zich niet vaak voordoen en dan geldt naar wij menen bovendien genoemd vermoeden), maar omdat de beschikbare feitelijke aanwijzingen elkaar 'tegenspreken', zoals in de zaak Faber (Faber was op weg naar een professionele afspraak met haar dochtertje toen haar auto vlam vatte).

De rechter moet overigens oog houden voor tegenstrijdige aanwijzingen om niet te snel tot de conclusie te komen dat er geen sprake is van een consument. Is het professionele bezorgadres het enige aanknopingspunt, dan heeft de rechter op het eerste gezicht weinig reden om in actie te komen. Wellicht heeft de koper het voor privégebruik gekochte echter op zijn werk laten bezorgen omdat hij door de week niet thuis is. In de praktijk zullen er naar wij aannemen dan meestal meer aanwijzingen zijn: het feit dat een natuurlijke persoon een beroep doet op de koopregeling, een rekeningnummer en de aard van het gekochte product. De rechter dient alle in het dossier beschikbare gegevens in ogenschouw te nemen om te bepalen of hij een nader onderzoek moet instellen naar de hoedanigheid van de koper.

De vervolgvraag is hoe de rechter moet bepalen of sprake is van een consument, althans of sprake is van een (door de verkoper te weerleggen) vermoeden. De beoordeling van de intenties van de koper kan subjectief of objectief plaatsvinden, de omstandigheden van het geval in acht nemend. Het Gru-

23. '(...) als de wederpartij een natuurlijke persoon is, en er zijn geen aanwijzingen voor een bedrijfsmatige transactie, mag er vanuit worden gegaan dat de wederpartij consument is, behoudens als de gebruiker het tegendeel stelt': LOVCK-rapport 'Ambtshalve toetsing II', november 2014, p. 11-12; zie ook A.G.F. Ancery, Ambtshalve toepassing van consumentenbeschermend EU-recht, MvV 2013, afl. 12, p. 335.

24. Een vordering tot betaling van de koopprijs daargelaten (art. 7:26 BW), maar deze bepaling vloeit niet voort uit de richtlijn. ber-arrest stelt een objectieve toets voorop, waarin gegevens als de aard van het gekochte, ${ }^{25}$ maar ook bijvoorbeeld een btwbon de doorslag geven. Een objectieve benadering heeft als voordeel dat het gerechtvaardigde vertrouwen van de verkoper wordt beschermd. ${ }^{26}$ De Nederlandse wet gaat echter uit van een subjectieve benadering, waarin de daadwerkelijke bedoelingen van de koper beslissend zijn. ${ }^{27}$ In het kader van het 'ambtshalve' vaststellen van de toepasselijkheid van de Richtlijn consumentenkoop ligt een objectieve benadering voor de hand: aangezien de consument dan (nog) niets heeft gesteld omtrent zijn hoedanigheid zullen subjectieve motieven niet bekend zijn. De rechter moet als gezegd een aanwijzing hebben dat mogelijk sprake is van een consument en dat hij ambtshalve op moet treden. Of hij daarna, bij het weerleggen van het vermoeden door de verkoper of een nader onderzoek op grond van art. $22 \mathrm{Rv}$, de keuze heeft tussen een subjectieve of objectieve weg is niet duidelijk.

Aan de beschikbare gegevens kan de rechter als gezegd een vermoeden ontlenen. Dit vermoeden is gebaseerd op objectieve gegevens, zoals de titel van de overeenkomst of de aard van het gekochte. In het Costea-arrest legt het $\mathrm{HvJ}$ de nadruk op dit laatste gegeven alsmede op de bewoordingen van de overeenkomst. ${ }^{28}$ Het spreekt voor zich dat de verkoper het vermoeden dat sprake is van een consumentenkoop altijd moet kunnen weerleggen. Een tussenvonnis waarin hem die mogelijkheid wordt geboden en ook wordt aangegeven welke benadering de objectieve of de subjectieve - de rechter volgt, lijkt ons geraden. Tenzij de verkoper het vermoeden tracht te weerleggen, zal de rechter onzes inziens evenwel niet hoeven verifieren of zijn vermoeden dat sprake is van een consument klopt (vergelijk r.o. 40). Een dergelijk onderzoek kost tijd en is niet altijd gunstig voor de koper.

Twijfelt de rechter als gevolg van tegenstrijdige aanwijzingen, zoals in onderhavige zaak, dan kan hij in zijn ambtshalve onderzoek in beginsel beide wegen bewandelen. Het HvJ geeft aan dat hij bij dit onderzoek gebruik moet maken van de door het nationale procesrecht geboden onderzoeksbevoegdheden (r.o. 42-45). De rechter dient zo nodig partijen om informatie te vragen. Naar Nederlands procesrecht bestaat die onderzoeksbevoegdheid: art. $22 \mathrm{Rv}$ (zie eveneens art. 88 en $89 \mathrm{Rv}$ ). ${ }^{29}$ De rechter kan terugvallen op een subjectieve aanpak door de consument te vragen naar zijn beweegredenen. Eveneens denkbaar is dat hij in geval van twijfel tracht vast te stellen waarop de verkoper gerechtvaardigd mocht vertrouwen,

25. Loos 2013, nr. 24.

26. B.B. Duivenvoorde, Consument of handelend in de uitoefening van beroep of bedrijf? Het Bundesgerichtshof doet uitspraak, TvC 2010, afl. 4, p. 176-177. Deze benadering betekent dat 'ook indien de handelaar weet dat zijn wederpartij geen "echte consument" is, deze toch als consument wordt aangemerkt'.

27. Asser/Hartkamp \& Sieburgh 6-III* 2010/500, waarop kritisch: Jac. Hijma, Algemene voorwaarden, in: Jac. Hijma e.a. (red.), Rechtshandeling en overeenkomst, Deventer: Kluwer 2013, nr. 243.

28. Vgl. Costea-arrest, r.o. 22-23.

29. Zie hierover Ancery \& Seinen 2015. 
gezien de in het dossier aanwezige en later aangedragen feiten en omstandigheden (een zuiver objectieve benadering). Helaas laat het HvJ zich niet expliciet uit over de te volgen aanpak. Gelet op de aanwijzingen in de Gruber-, Faber- en Costeaarresten lijkt de laatste aanpak ons de juiste.

\section{De toepassing van de koopregeling: fase twee}

Het $\mathrm{HvJ}$ heeft in deze uitspraak ook vragen beantwoord met betrekking tot de toepassing van de koopregeling en meer in het bijzonder de bewijslastomkering bij een beroep op nonconformiteit door de koper en die bij het verweer van de verkoper dat de koper te laat heeft geklaagd. Deze laatste in de vijfde prejudiciële vraag geadresseerde problematiek komt als eerste aan de orde. In de praktijk zal immers eerst worden beoordeeld of er tijdig is geklaagd, aangezien hieraan dient te zijn voldaan om voor de remedies bij een eventuele non-conformiteit in aanmerking te komen.

\subsection{De klachtplicht}

Uit art. 7:23 lid 1 BW laatste zin blijkt dat bij een consumentenkoop de kennisgeving dat sprake is van non-conformiteit binnen bekwame tijd na de ontdekking hiervan moet geschieden, waarbij een kennisgeving binnen een termijn van twee maanden na de ontdekking tijdig is. Een langere termijn kan in beginsel dus ook nog tijdig zijn. De richtlijn staat toe dat deze twee maanden een maximum vormen (considerans nr. 19 en art. 5 lid 2 Richtlijn consumentenkoop). Het HvJ haalt de ontstaansdocumentatie van de richtlijn aan om de achtergrond van dit artikel te schetsen:

'61. Volgens de voorstukken van die richtlijn beantwoordt die mogelijkheid aan de behoefte om de rechtszekerheid te versterken door de koper aan te zetten tot een "zekere waakzaamheid, terwijl (...) tegelijk de belangen van de verkoper in aanmerking [worden genomen]", "zonder hem een strikte verplichting op te leggen tot een minutieus onderzoek van het goed" [zie de memorie van toelichting bij het voorstel voor een richtlijn $\operatorname{COM(95)~} 520$ def., blz. 14].'

De Nederlandse wettekst is dus zonder meer in overeenstemming met de richtlijn. De vraag is of de bijbehorende bewijslastverdeling dit ook is. Het Hof Arnhem-Leeuwarden vroeg zich in het bijzonder af of de verdeling van de bewijslast naar Nederlands recht bij de toepassing van de klachttermijn (waaronder ook die ex art. 7:23 lid 1 BW) wel was toegestaan in het licht van het effectiviteitsbeginsel.

Opmerkelijk is dat in de tijd dat de prejudiciële procedure aanhangig was bij het $\mathrm{HvJ}$ deze verdeling van de bewijslast is afgezwakt door de Hoge Raad. De prejudiciële vraag is gebaseerd op de verdeling van de bewijslast zoals die volgde uit het arrest Ploum/Smeets I. ${ }^{30}$ Volgens dit arrest diende de koper/ schuldeiser te stellen en te bewijzen dat hij de verkoper/schul-

30. HR 23 november 2007, NJ 2008/552 (Ploum/Smeets en Geelen Tankstations BV). denaar binnen bekwame tijd (dat wil zeggen tijdig) op de hoogte had gebracht van de non-conformiteit. Volgens een in december 2014 gewezen arrest moet de koper, wanneer de verkoper het verweer voert dat niet tijdig is geklaagd, (slechts) stellen en zo nodig bewijzen dat en wanneer hij heeft geklaagd, waarna het weer aan de verkoper is om an te tonen dat deze klacht toch echt te laat was. ${ }^{31}$ Deze bewijslastverdeling, waarbij het aan de koper is te bewijzen dat en wanneer hij geklaagd heeft, betreft volgens de Hoge Raad een bijzondere regel van bewijslastverdeling als bedoeld in art. $150 \mathrm{Rv}$. Hij wordt naar nationaal recht gerechtvaardigd door de omstandigheid dat de klachtplicht de strekking heeft de belangen van de verkoper te beschermen.

Het HvJ laat zich niet expliciet uit over de specifieke bewijslastverdeling naar Nederlands recht. Een bepaalde bewijslastverdeling is met het oog op het effectiviteitsbeginsel volgens het HvJ slechts toegestaan voor zover zij het voor de consument niet onmogelijk of uiterst moeilijk makt om zijn rechten uit te oefenen.

'64. Op het bewijs dat die kennisgeving aan de verkoper is gedaan, zijn in beginsel de nationale voorschriften op dit gebied van toepassing, die evenwel in overeenstemming moeten zijn met het effectiviteitsbeginsel. Bijgevolg mag een lidstaat geen eisen stellen die de uitoefening door de consument van de door hem aan richtlijn 1999/44 ontleende rechten onmogelijk of uiterst moeilijk kunnen maken.'

De door de Hoge Raad aangebrachte nuance (de koper draagt niet langer het bewijsrisico ten aanzien van het tijdig klagen, ${ }^{32}$ maar de verkoper draagt dit risico ten aanzien van het niet tijdig klagen) doet er in het licht van het antwoord van het $\mathrm{HvJ}$ wellicht toe omdat het voor de koper eenvoudiger wordt om zijn rechten uit te oefenen. Even goed denkbaar is dat de verdeling onder Ploum/Smeets I reeds de toetsing aan het effectiviteitsbeginsel doorstond, zeker als de Ploum/Smeets-benadering zoals uitgelegd door A-G Wissink juist is. ${ }^{33}$ Het antwoord van het HvJ geeft te weinig aanknopingspunten om een definitief oordeel te vellen over de thans op de schouders van de consument-koper rustende bewijslast. De discussie is geopend.

Interessant is dat het $\mathrm{HvJ}$ de vraag aanwendt om de wijze van uitoefening van de klachtplicht toe te lichten. Het HvJ benadrukt dat de consument minimaal twee maanden de tijd moet hebben om te klagen (dat heeft hij naar Nederlands recht) en

31. HR 12 december 2014, ECLI:NL:HR:2014:3593 (Far Trading/Edco Eindhoven). Overigens had A-G Wissink al in zijn conclusie voorafgaand aan HR 17 december 2010, ECLI:NL:HR:2010:BO2873, RvdW 2011/20 aangegeven dat dit zijns inziens ook de route onder Ploum/ Smeets I was.

32. Of tijdig is geklaagd, is bijvoorbeeld afhankelijk van het nadeel dat de verkoper heeft ondervonden door het tijdsverloop tot aan de klacht.

33. A-G Wissink in zijn conclusie voorafgaand an HR 17 december 2010, ECLI:NL:HR:2010:BO2873, RvdW 2011/20, sub. 2.18.3. 
dat in het kader van de uitoefening van de klachtplicht niet van de consument mag worden verwacht dat hij meer doet dan de verkoper op de hoogte stellen van de non-conformiteit. Uit de klacht van de koper moet wel voldoende duidelijk blijken over welk gebrek aan het geleverde wordt geklaagd. In dat opzicht verschaft het HvJ een aantal gezichtspunten:

'63. Wat de inhoud van die kennisgeving betreft, kan de consument in dat stadium niet worden verplicht te bewijzen dat een gebrek aan overeenstemming werkelijk een invloed heeft op het door hem gekochte goed. Aangezien de consument in vergelijking met de verkoper minder informatie tot zijn beschikking heeft over de eigenschappen van dat goed en de staat waarin dit is verkocht, kan hij evenmin worden verplicht de precieze oorzaak van dat gebrek aan overeenstemming aan te geven. Opdat de kennisgeving nuttig is voor de verkoper, moet zij daarentegen een aantal aanwijzingen bevatten - waarvan de mate van nauwkeurigheid noodzakelijkerwijs varieert naargelang van de omstandigheden van iedere zaak - over de aard van het betrokken goed, de inhoud van de desbetreffende koopovereenkomst en de wijze waarop het gestelde gebrek aan overeenstemming zich concreet heeft gemanifesteerd.'

De klacht moet nuttig zijn voor de verkoper: hij moet zich kunnen voorbereiden op wat komen gaat. Gaat hij de aansprakelijkstelling bevechten? Zo ja, dan zal hij zo veel mogelijk informatie willen verzamelen om het eventuele bewijsvermoeden te kunnen weerleggen of, indien er geen sprake is van een vermoeden, om verweer te voeren. Zo niet, dan moet hij nadenken over de mogelijke remedies. Is vervanging mogelijk (dat is niet het geval bij tweedehands zaken), is reparatie haalbaar of is ontbinding de beste optie?

De klachtplichtregeling wordt niet ambtshalve toegepast. ${ }^{34}$ Het arrest Ploum/Smeets I werd in de literatuur echter aldus uitgelegd, dat de koper, om in aanmerking te komen voor de hem toekomende remedies, diende te stellen dat hij tijdig geklaagd had, zonder dat de verkoper al een beroep had gedaan op de klachtplicht. Of er voldoende gesteld is, wordt door de rechter ambtshalve getoetst. Op die manier zou de klachtplicht wel ambtshalve worden toegepast. ${ }^{35}$ Of deze lezing nu juist is of niet, thans is op grond van Far Trading/Edco II de verkoper eerst aan zet. Het is de verkoper die bij wege van verweer moet opwerpen dat de consument te laat heeft geklaagd. De Hoge Raad heeft geoordeeld dat een beroep op de klachtplicht een bevrijdend verweer is. De verkoper stelt en bewijst dat er niet tijdig is geklaagd en voorziet de rechter van de fei-

34. HR 20 januari 2006, NJ 2006/80.

35. De precieze rol van de rechter was lang onderwerp van debat. Zie H.B. Krans, Bewijslastverdeling en klachtplicht, AA 2009, p. 188-190; W.L. Valk, Klachtplicht en bewijslast, NTBR 2008, p. 94-97. Met het arrest van eind 2014 heeft de Hoge Raad duidelijkheid verschaft, dit in lijn met hetgeen A-G Wissink in zijn conclusie voorafgaand aan HR 17 december 2010, ECLI:NL:HR:2010:BO2873, RvdW 2011/20 al had voorgesteld. Over het Far Trading/Edco II-arrest: F.J.P. Lock, Klachtplicht en bewijslast; omzwervingen van de Hoge Raad, TvPP 2015, afl. 1, p. 3-8. ten en omstandigheden om dat verweer te beoordelen. Het is dus aan de verkoper om aan te geven wanneer de klachttermijn is gaan lopen en dat het moment dat is verstreken tussen de aanvang van de termijn en het moment waarop feitelijk is geklaagd als te lang dient te worden aangemerkt. En het is de koper op wie vervolgens de stelplicht en bewijslast wordt gelegd dat er geklaagd is en op welk moment er geklaagd is. ${ }^{36}$ De rechter heeft daarin ambtshalve geen rol, hoogstens dat hij dient te beoordelen of partijen voldoende hebben gesteld om voor bewijslevering in aanmerking te komen. Ten aanzien van de stelplicht van de consument-koper lijkt een soepele benadering ons overigens wel geïndiceerd om te voorkomen dat de consument via de stelplicht alsnog verstoken blijft van de remedies waarop hij krachtens de Richtlijn consumentenkoop recht zou hebben.

\subsection{Non-conformiteit en bewijsvermoeden}

Omdat Hazet BV een geslaagd beroep deed op de schending van de klachtplicht, is in eerste instantie niet getoetst of de afgeleverde auto in overeenstemming was met de overeenkomst. Faber beroept zich in hoger beroep opnieuw op de non-conformiteit van de auto. Omdat zij de auto vier maanden voor de brand heeft gekocht, richt het Hof Arnhem-Leeuwarden zijn aandacht op het bewijsvermoeden.

Het peilmoment van de conformiteit is het moment van aflevering (art. 3 lid 1 Richtlijn consumentenkoop). Een consument die een product koopt en binnen een halfjaar na aflevering wordt geconfronteerd met een gebrek in dat product kan profiteren van de bewijslastomkering van art. 5 lid 3 van de Richtlijn consumentenkoop. Daarin is bepaald dat een gebrek dat zich binnen zes maanden na aflevering manifesteert, wordt vermoed reeds aanwezig te zijn geweest bij aflevering. De gedachte achter deze verlichting van de bewijslast is dat het voor de verkoper doorgaans eenvoudiger is om aan te tonen dat het gebrek niet bestond ten tijde van de aflevering, maar dat het is ontstaan als gevolg van bijvoorbeeld een verkeerd gebruik door de consument (r.o. 54). Het vermoeden heeft slechts een 'temporele lading' ${ }^{37}$ en de consument moet zelf nog wel 'het niet beantwoorden aan de overeenkomst' bewijzen (art. 2 lid 2 Richtlijn consumentenkoop). De toepassing van het bewijsvermoeden heeft daarom iets van een tweetrapsraket: de consument moet stellen en zo nodig bewijzen dat sprake is van een gebrek (stap 1) en als dit lukt, dan wordt de non-conformiteit vermoed te hebben bestaan ten tijde van de aflevering (stap 2). Art. 5 lid 3 van de Richtlijn consumentenkoop is geïmplementeerd in art. 7:18 lid $2 \mathrm{BW}$, terwijl art. 7:17 lid 2 BW de conformiteitstoets bevat. In lijn met de richtlijn zijn bepaalde producten uitgesloten van de werking van het bewijsvermoeden (bederfelijke producten bijvoorbeeld). Vooropgesteld zij dat het feit dat het in casu om een gebruikte auto gaat, zich niet verzet tegen de toepassing van

36. HR 12 december 2014, ECLI:NL:HR:2014:3593, RvdW 2015/66 (Far
Trading/Edco II). 37. Hijma 2013, p. 259. 


\section{Maandblad \\ Vermogensrecht}

het bewijsvermoeden (stap 2). ${ }^{38}$ Dit gegeven speelt wel een rol bij de vraag of sprake is van een gebrek aan overeenstemming met de overeenkomst ( $\operatorname{stap} 1) .{ }^{39}$

De door het hof ingediende vraag strekt niet tot het verkrijgen van aanwijzingen bij de afweging van gezichtspunten bij de conformiteitstoets, maar betreft de bewijspositie van de consument bij eerdergenoemde stap 1 . Het antwoord van het $\mathrm{HvJ}$ weidt anders dan bij de vorige vraag niet verder uit over de invulling van de conformiteitstoets door gezichtspunten aan te reiken. Het antwoord van het $\mathrm{HvJ}$ gaat wel iets verder dan de gestelde vraag door behalve op de bewijspositie van de consument bij stap 1 ook in te gaan op die van de verkoper bij stap 2. Bij de beantwoording van de vraag naar de op de consument rustende bewijslast kiest het $\mathrm{HvJ}$ iets andere bewoordingen dan het verwijzende hof. Waar het Hof ArnhemLeeuwaarden informeert of de consument bij stap 1 kan volstaan met te stellen (en zo nodig bewijzen) 'dat het gekochte niet (goed) functioneert', prefereert het $\mathrm{HvJ}$ de volgende formulering:

'70. In de eerste plaats moet de consument stellen en bewijzen dat het verkochte goed niet in overeenstemming is met de betrokken overeenkomst, doordat het bijvoorbeeld niet de in die overeenkomst vastgestelde eigenschappen bezit of ongeschikt is voor het doorgaans van dit soort goederen verwachte gebruik.'

Het $\mathrm{HvJ}$ voegt hier expliciet aan toe dat de consument bij stap 1 ook moet bewijzen dat het betrokken gebrek aan overeenstemming zich binnen een termijn van zes maanden vanaf de aflevering van het goed heeft gemanifesteerd, dat wil zeggen zich werkelijk heeft voorgedaan' (r.o. 71).

De vraag van het hof of de consument-koper ook moet stellen en zo nodig bewijzen welk gebrek aan het verkochte dit niet (goed) functioneren veroorzaakt (heeft), wordt in r.o. 75 ontkennend beantwoord: 'De consument is niet verplicht om de oorzaak van dat gebrek aan overeenstemming te bewijzen of te bewijzen dat de oorsprong van dat gebrek te wijten is aan de verkoper.' Uit de daaraan voorafgaande overwegingen blijkt dat de bewijslast met betrekking tot de oorzaak van het gebrek bij de toepassing van het bewijsvermoeden juist is omgedraaid $^{40}$ en bij de verkoper ligt. Wederom refereert het HvJ aan de totstandkomingsgeschiedenis van de richtlijn:

'72. Indien die feiten [een gebrek aan overeenstemming dat zich binnen zes maanden heeft voorgedaan; AGFA \& CMDSP] zijn aangetoond, hoeft de consument niet te bewijzen dat het gebrek aan overeenstemming bestond bij de aflevering van het goed. Aangezien dat gebrek zich in de korte periode van zes maanden heeft voorgedaan, kan worden aangenomen dat het, ook al heeft het zich pas na de

38. Vgl. Rb. Leeuwarden 29 april 2011, ECLI:NL:RBLEE:2011:BQ3070. 39. Vgl. Rb. Rotterdam 10 juli 2015, ECLI:NL:RBROT:2015:6144.

40. Anders: Kamerstukken I 2002/03, 27809, 32a, p. 3 (nadere MvA). aflevering van het goed voorgedaan, bij de aflevering reeds bestond "in een pril stadium" (zie de memorie van toelichting bij het voorstel voor een richtlijn $\operatorname{COM}(95) 520$ def., blz. 12).

73. Het staat dan aan de verkoper om in voorkomend geval te bewijzen dat het gebrek aan overeenstemming niet bestond bij de aflevering van de goederen, door aan te tonen dat dit gebrek het gevolg is van of zijn oorsprong vindt in een handelen of nalaten dat dateert van na die aflevering.'

Interessant is dat het $\mathrm{HvJ}$ aldus ingaat op de bewijslast die bij toepassing van art. 7:18 lid $2 \mathrm{BW}$ - stap 2 - op de verkoper rust. Hier had het Hof Arnhem-Leeuwarden nu juist geen vraag over gesteld. En dit is opvallend. Dit hof staat immers bekend om zijn van de parlementaire geschiedenis bij de omzetting van de richtlijn afwijkende lijn. Van deze lijn is gezegd dat zij meer in overeenstemming was met de richtlijn dan de toelichting bij de nationale omzettingswetgeving. ${ }^{41}$ In de voorliggende zaak zag het hof kennelijk geen aanleiding om door middel van een prejudiciële vraag een einde aan de langlopende discussie te maken. Het HvJ laat de gelegenheid echter niet onbenut om de bewijslast van de verkoper nader toe te lichten. Het HvJ vervolgt:

'74. Indien de verkoper niet erin slaagt rechtens genoegzaam te bewijzen dat het gebrek aan overeenstemming het gevolg is van of zijn oorsprong vindt in een omstandigheid die zich na de aflevering van de goederen heeft voorgedaan, biedt het in artikel 5, lid 3, van richtlijn 1999/44 neergelegde vermoeden de consument de mogelijkheid om de rechten te doen gelden die hij aan die richtlijn ontleent.'

Vaststaat dat hiermee de discussie over de bewijspositie van de verkoper is beslecht. Twijfel zaaien is niet genoeg. Het gaat bij art. 7:18 lid $2 \mathrm{BW}$ om bewijs van het tegendeel. De verkoper moet, teneinde het vermoeden te weerleggen, 'rechtens genoegzaam' bewijzen dat het gebrek aan overeenstemming niet bestond bij de aflevering van de zaken. Het HvJ overweegt evenwel niet met zoveel woorden dat de verkoper moet bewijzen dat de zaak bij haar aflevering wel dégelijk aan de overeenkomst beantwoordde, ${ }^{42}$ maar kiest voor negatieve formulering (bewijs dat er bij aflevering geen sprake was van nonconformiteit). Voorts geeft het HvJ aan hoe de verkoper het tegendeel kan bewijzen. De verkoper kan hiertoe aantonen dat het gebrek is veroorzaakt door of voortgekomen uit een omstandigheid die plaatshad na de aflevering. Er is naar wij menen echter pas sprake van bewijs van het tegendeel indien uit dit bewijs a contrario volgt dat het gebrek bij de aflevering niet bestond.

41. Jac. Hijma, Consument en non-conformiteitsbewijs, TvC 2013, afl. 6, p. 258-259.

42. Vgl. Hijma 2013, p. 258. 
Men neme het voorbeeld van een hond die binnen zes maanden na aankoop ziek wordt en overlijdt. De verkoper bewijst dat de hond is overleden aan een bacteriële longontsteking, een aandoening met een snel verloop. Hij lijkt te hebben aangetoond dat het gebrek het gevolg is van een omstandigheid die zich na de aflevering heeft gemanifesteerd. Op het eerste gezicht lijkt het vermoeden van non-conformiteit weerlegd: de hond is overleden aan een ziekte die niet aanwezig kon zijn ten tijde van de aankoop. Hiermee is echter niet gezegd dat de hond op dat moment a contrario gezond was. De hond kan bij aflevering zeer wel bijzonder vatbaar zijn geweest voor een longaandoening. Als wordt aangenomen dat het vermoeden pas is weerlegd indien voldoende blijkt dat de hond bij aflevering gezond, althans niet ongezond was - de door het Hof Arnhem-Leeuwarden gevolgde lijn - dan volstaat het aangeleverde bewijs niet. Het identificeren van de oorzaak of oorsprong van het gebrek vormt pas bewijs van het tegendeel indien er strenge eisen aan die identificatie worden gesteld: is de longontsteking de enige oorzaak of was de hond hier door zijn gestel bijzonder vatbaar voor en is dit zwakke gestel de eigenlijke oorzaak van het gebrek? De sleutel zit in de woorden 'rechtens genoegzaam bewijzen'. Indien een dieperliggende oorzaak niet voldoende kan worden uitgesloten - denk ook aan de vraag of ondeskundig gebruik of ondeugdelijk materiaal de oorzaak is van beschadigingen ${ }^{43}$ - dan heeft de verkoper het bewijs van het tegendeel naar wij menen niet 'ten volle' geleverd. Het arrest schept helaas onvoldoende duidelijkheid op dit punt.

\subsection{Ambtshalve toepassing van de bewijslastomkering ex art. $7: 18$ lid $2 \mathrm{BW}$}

Het HvJ overweegt dat het bewijsvermoeden dwingendrechtelijk van aard is (r.o. 55). Van dit bewijsvermoeden mag niet ten nadele van de consument worden afgeweken. Maar het gaat nog verder, zo blijkt uit het Faber-arrest. Het dient te worden toegepast, zelfs als de consument er geen beroep op doet en ambtshalve is vastgesteld dat de richtlijn van toepassing is (zie hiervoor par. 2). Het HvJ merkt desgevraagd ${ }^{44}$ het vermoeden aan als een norm die gelijkwaardig is aan nationale regels die in de interne rechtsorde hebben te gelden als normen van openbare orde. Als de nationale rechter de mogelijkheid heeft om een dergelijke norm ambtshalve toe te passen, is hij verplicht om het bewijsvermoeden van art. 5 lid 3 van de Richtlijn consumentenkoop ambtshalve toe te passen (r.o. 56).

De ambtshalve toepassing binnen de context van de Richtlijn consumentenkoop bestaat aldus, net als bij de Richtlijn oneerlijke bedingen, uit twee stadia: de ambtshalve vaststelling dat de richtlijn van toepassing is (zie par. 2) wordt gevolgd door de ambtshalve toepassing van de beschermende bepalingen (r.o.

43. Zie ook het voorbeeld genoemd door P. Klik, Consumentenkoop van roerende zaken, in: E.H. Hondius \& G.J. Rijken, Handboek consumentenrecht (4de druk), Zutphen: Uitgeverij Paris 2015, p. 136: Rb. Breda 4 juni 2008, NJF 2008/332.

44. De vierde prejudiciële vraag is toegespitst op het bewijsvermoeden.
51). ${ }^{45}$ De ambtshalve toepassing van de oneerlijkheidstoets kan (en moet) plaatsvinden, ook al laat de consument verstek gaan. De ambtshalve toepassing van het bewijsvermoeden kan niet volledig buiten de consument om plaatsvinden. Voordat aan bewijslevering kan worden toegekomen en het bewijsvermoeden dus eventueel (desnoods ambtshalve) kan worden toegepast, dient de consument voldoende te stellen om tot bewijslevering te worden toegelaten. Hij moet de elementen en de feiten die benodigd zijn voor non-conformiteit dus voldoende gespecificeerd stellen (stap 1), ${ }^{46}$ waarna de rechter ambtshalve dient vast te stellen dat het gebrek wordt vermoed reeds aanwezig te zijn geweest ten tijde van de aflevering van het product (stap 2).

Wat heeft dan te gelden als de consument niet kwalificeert voor bewijslevering omdat hij niet aan de stelplicht voldoet? Via de stelplicht kan de toepassing van het consumentenbeschermende bewijsvermoeden immers worden gefrustreerd. Bovendien kan hiervan in het licht van de ratio voor de consumentenbescherming worden gezegd dat als het aan de consument moet worden gelaten om de juiste elementen te stellen het gevaar bestaat dat hij verstoken blijft van de hem toekomende bescherming. Een welwillende benadering met betrekking tot het door de consument gestelde lijkt dan ook geïndiceerd. De lat moet niet te hoog worden gelegd voordat de consument voor bewijslevering in aanmerking komt.

De volgende vraag is hoe soepel de rechter zich zou moeten opstellen. Hiervoor beschreven we dat de consument moet stellen en bewijzen dat het door hem aangeschafte product gebrekkig is, en bij verweer dat er niet tijdig is geklaagd, dat hij geklaagd heeft en op welk moment. De stelplicht voor de nonconformiteit kan onzes inziens onverminderd worden gehandhaafd. De consument zal daar voldoende moeten stellen om voor bewijslevering in aanmerking te komen. Als de consument slaagt in die bewijslevering, kan de rechter vervolgens ambtshalve toepassing geven aan het vermoeden van art. 7:18 lid 2 BW. In eerste aanleg zal de rechter het bewijsvermoeden ambtshalve moeten toepassen als de consument zich daar niet op beroept. Het HvJ giet deze verplichting in het vat van het gelijkwaardigheidsbeginsel. De (on)mogelijkheden van het nationale recht staan dan ook voorop. De Nederlandse rechter treedt niet buiten de grenzen van de rechtsstrijd, tenzij het een kwestie van openbare orde betreft. Het HvJ merkt het volgende op over het bewijsvermoeden van art. 5 lid 3 van de Richtlijn consumentenkoop (art. 7:18 lid 2 BW):

'56. Gelet op de aard en het gewicht van het openbare belang waarop de door artikel 5, lid 3, van richtlijn 1999/44 aan de consument geboden bescherming berust,

45. Zie HR 13 september 2013, ECLI:NL:HR:2013:691, waarover C.M.D.S. Pavillon, Het Heesakkers/Voets-arrest en de twee stadia van de ambtshalve oneerlijkheidstoets, TvPP 2014, afl. 3, p. 81-89.

46. Vgl. bijv. K.M. Sikorska, The Presumption of Non-Conformity in European Consumer Sales Law (diss. Groningen), Den Haag: Eleven International Publishing 2015, p. 39. 


\section{Maandblad \\ Vermogensrecht}

moet die bepaling worden beschouwd als een norm die gelijkwaardig is aan een nationale regel die in de interne rechtsorde als regel van openbare orde geldt. Wanneer de nationale rechter in zijn nationale rechtsplegingssysteem over de mogelijkheid beschikt om een dergelijke norm ambtshalve toe te passen, is hij bijgevolg verplicht om iedere bepaling van zijn nationale recht waarbij dat artikel 5, lid 3, is omgezet ambtshalve toe te passen (...).'

Wat betekent dit voor de Nederlandse rechter? Ambtshalve onderzoek buiten het dossier mag hij op grond van art. $149 \mathrm{Rv}$ niet verrichten, al biedt het civiele procesrecht daar via instructiebevoegdheden nog wel enige ruimte voor. De rechter zal al vaak kunnen vaststellen dat het gebrek zich binnen zes maanden na aflevering heeft gemanifesteerd aan de hand van het door partijen overgelegde koopcontract. Resteert er toch nog enige onduidelijkheid op dit punt, dan kan de rechter partijen vragen om die onduidelijkheid weg te nemen door aanwending van de in art. $22 \mathrm{Rv}$ neergelegde bevoegdheid. Een verplichting vormt dat onzes inziens niet, omdat de rechter ook bij nationale bepalingen van openbare orde geen onderzoeksplicht heeft in de zin waarin deze wordt geformuleerd door het HvJ. ${ }^{47}$

In appel - de prejudiciële vraag werd immers in het kader van de appelprocedure gesteld - krijgt de ambtshalve toepassing van bepalingen van openbare orde een bijzondere dimensie. De devolutieve werking van het appel brengt met zich dat aan deze bepalingen pas toepassing kan worden gegeven als de daarvoor benodigde feitelijke informatie met een van de voorgestelde grieven in het geding is gebracht. Het appelprocesrecht doet in zoverre niets af aan de hiervoor geformuleerde stelplicht van verkoper en consument, maar wel aan de mogelijkheden om ambtshalve toepassing te geven aan consumentenbeschermende bepalingen. Die zijn door het concept devolutieve werking in appel nou eenmaal beperkter. Na toepassing van een bepaling van openbare orde mag de appelrechter overigens wel vernietigen op een grond waarover partijen niet hebben gegriefd, zolang hij maar binnen de door de aan de grieven ten grondslag gelegde gegevens bepaalde rechtsstrijd blijft.

Zowel in appel als in eerste aanleg geldt overigens weer dat de bijstand door een advocaat geen afbreuk doet aan de plicht van de rechter om ambtshalve toepassing te geven aan het bewijsvermoeden. Deze plicht geldt los van alle concrete omstandigheden van het geval.

\section{Conclusie}

Het tweede arrest van het HvJ over ambtshalve toetsing in het kader van de Richtlijn consumentenkoop biedt verduidelijkingen en leidt ook weer tot vragen. De onderzoeksplicht van de rechter zoals die werd geformuleerd in het Pénzügyi-arrest lijkt te kunnen worden doorgetrokken naar de Richtlijn con- sumentenkoop. Als de rechter door aanwending van instructiebevoegdheden zoals art. $22 \mathrm{Rv}$ eenvoudig kan beschikken over de noodzakelijke gegevens, feitelijk en rechtens, om te komen tot een kwalificatie van de rechtsverhouding, dient hij daar onderzoek naar te doen. Onzes inziens zal de aangewezen aanpak in de praktijk zijn dat de rechter behoudens contraindicaties aanvaardt dat het een b2c-verhouding is en bij contra-indicaties informatie inwint bij de koper en de verkoper in staat stelt om aan te tonen dat het wel een b2b-geschil is. Voorkeur verdient een benadering waarin bepalend is of naar buiten toe het privégebruik overheerst.

Als de rechtsverhouding is gekwalificeerd, komen meer consumentenkoopvragen aan de orde. Hoe dient de rechter om te gaan met art. 7:18 lid $2 \mathrm{BW}$ ? Het HvJ maakt duidelijk dat deze bepaling gelijk te stellen is met nationale bepalingen van openbare orde. De Nederlandse rechter dient er dus ambtshalve toepassing aan te geven buiten de grenzen van de rechtsstrijd, zij het dat de mogelijkheden daartoe in appel iets beperkter zijn vanwege de devolutieve werking. Overigens dient het belang van deze plicht tot ambtshalve toepassing van art. 7:18 lid 2 BW te worden gerelativeerd. Dit bewijsvermoeden wordt pas actief als de consument stelt en weet te bewijzen dat het een non-conform product betreft. Lukt dat, dan wordt vermoed dat het product al non-conform was op het moment dat het werd afgeleverd en dat dient de rechter dan ambtshalve te constateren, ongeacht of de consument daarop een beroep doet. In zoverre zijn dit dan ook wezenlijk andere zaken dan de zaken die handelen over oneerlijke bedingen, waarin de consument vak niet verschijnt en de rechter zo bezien alerter dient te zijn op mogelijk oneerlijke bedingen. Dat de ambtshalve toepassing van art. 7:18 lid 2 BW de rechter zal ontgaan, lijkt ons veel onwaarschijnlijker.

De consument hoeft slechts aan te tonen dat het product nonconform is en niet wat de oorzaak is van deze non-conformiteit. In het geval van mevrouw Faber zal dat vermoedelijk niet al te veel problemen opleveren: een rijdende auto hoort niet spontaan vlam te vatten. Voordat wordt toegekomen aan het bewijzen van die non-conformiteit, zal de rechter al kunnen beoordelen of door de koper tijdig is geklaagd over de gestelde non-conformiteit. Daar komt hij echter pas aan toe als de verkoper dat bevrijdende verweer voert. In aansluiting op dat verweer dient de consument-koper te stellen en te bewijzen dat hij heeft geklaagd, zo volgt uit het Far Trading/Edco II-arrest van de Hoge Raad. Betreft het de uit de Richtlijn consumentenkoop voortvloeiende klachtplicht, dan lijkt een consumentenvriendelijke toepassing ons in die zin geïndiceerd, dat de rechter niet al te zware eisen stelt aan de stelplicht van de consument-koper. Slaagt de consument in het bewijs dat hij heeft geklaagd, dan is het aan de verkoper om te bewijzen dat die klacht niet tijdig was. De benadering van de Hoge Raad met betrekking tot de bewijslastverdeling bij de klachtplicht blijft overeind: Het HvJ laat zich hier in het arrest niet over uit.

47. In deze zin lezen wij ook: Seinen 2014, p. 84 e.v. 


\section{Maandblad}

$\mathrm{Na}$ de klachtplicht en de non-conformiteit zijn de rechter en de verkoper aan zet. De rechter geeft ambtshalve toepassing aan art. 7:18 lid 2 BW, waarna de verkoper tegenwijs kan aandragen dat het vermoeden ontzenuwt. Twijfel zaaien is niet voldoende, de verkoper moet bewijzen dat het gebrek niet bestond ten tijde van de aflevering. Dat bewijs lijkt in het geval van Hazet BV lastig te leveren. Hoewel niet uitgesloten is dat de auto vlam heeft gevat omdat mevrouw Faber er bijvoorbeeld in het geheel geen onderhoud aan verrichtte - stel, het reservoir voor de koelvloeistof was geheel leeg - zal dat toch moeilijk te bewijzen zijn nu de auto is gedemonteerd. Of leggen we de lat nu te hoog voor de verkoper? Toekomstige arresten zullen daarover uitsluitsel moeten bieden. 